curious enumeration of historical facts occurring every 177 days, for the space is limited. Only, by the way, I note that Professor Thomas interprets phonetically Xaman as " north," the character that. in reality, designates nohol "south" (see the evidence adduced by me in "Zeitschrift für Ethnologie," XXIII., p. 104). His third sample of the use of his "letterglyph" $b$ is one of those interesting hieroglyphs that change the so-called "prefix" according to the four cardinal points. Compare Figs. 47,48 of the adjoined table, the former taken from Codex Dresden $29,30^{\mathrm{c}}$, the latter from Codex Tro. $31,30 \mathrm{~d}$. These varying elements un. doubtedly are indicating the names of colors, as each of the four cardinal points was distinguished by a special color. And the so-called letterglyph $b$, with all probability, has to be considered as expressing the element Kan " yellow" (see "Zeitscrift für Ethnologie," XXIII., p. 108, 109). The explanation Professor Thomas gives of the five dots, seen under certain hieroglyphs, as rendering the sound ho "five," will receive a curious illustration by the varied form these dots exhibit, for instance, in the Fig. 35b, taken from the Dresden Codex. It does not appear, with all, that the samples of interpretation presented by Professor Thomas in his last paper are more satisfactory than those of his former one. It will be seen, indeed, that there is no reliance in the simple fact that, applying a certain key, the parts give apparently appropriate results. In a similar way there could be proved and has been proved that the Mexican and Peruvian languages are derived from Sanscrit, and that the descendants of the lost tribes of Israel survive in the Southern Sea. The right, Professor Thomas claims, to apply such a key has to be proved in the first place. I am awaiting if, in the paper he is preparing for publication by the Bureau of Ethnology, he will be able to do so.

Steglitz, Germany, Dec 18. Dr. SELER.

\section{Irrigation Surveys.}

I HAVE just had the pleasure of perusing your issue of the $16 \mathrm{th}$, with its review of Irrigation Work by the General Government. Allow me, in returning my thanks for the comprehensice references made, to make some brief corrections:-

In the first place, then, the expenditures of the Geological Survey as to "irrigation" work, have been that of two appropriations - in all $\$ 350,000$. This is wholly outside of printing, which is paid for under other appropriations. The cost thereof will not be less than $\$ 15,000$. Besides these two direct sums of $\$ 100,000$ and $\$ 250,000$, with the printing of Part IL. in Annual Reports 10 and 11, the Survey for work in the Arid Region, topographic and hydrographic, has had two more annual appropriations of not less than $\$ 100,000$ in all. The terms of the appropriations were designed unquestionably to continue indirectly irrigation work which Congress had declared should not be continued by the Geological Survey. Its irrigation work, then, has cost much nearer $\$ 500,000$ than it has $\$ 235,000$. Its results are two finely printed volumes - one of 123 pages and the other of 395. In the latter are 80 or 90 pages of matter previously printed the larger part of it, indeed, having been twice printed by committees of the Senate and House. The reprint in Report Eleven is of Major Powell's testimony and argument before the House Select Committee on Irrigation, 51st Congress, which in substance and effect is the same that Director Powell made to the Senate Committee at the same session. So, in effect, it has cost nearly half a million dollars to publish 419 pages of " original" reports. There are no topographical maps of significance as yet issued.

Now, the Department of Agriculture, under its office of Artesian and Underflo' $x$ Investigation, and of Irrigation Inquiry, received and expended between April 15, 1890, and May 1, 1892. just two years, the munificent sum of $\$ 70,000$. During that time it made and has reported on two engineering, geological. and economic examinations of the Great Plains region, between $97^{\circ}$ and $105^{\circ}$ of longitude. and two reports besides on Irrigation proper. It prepared and issued six volumes in all, - a report on Artesian Wells, and the three parts you have noticed of the closing report on Artesian and Underflow Waters, also Progress Irrigation Report for 1891 , and the volume referred to as "miscellaneous" by the re- view. As the work is in part only my own, though I edited all of it, I can justly challenge the value of it all in quality, as much as I may claim it exceeds the report in quantity, as compared with the Geological Survey. The three reports (six volumes or parts) embrace in all 1,694 pages, and some 58 valuable profiles, maps and geologic sections, besides more than 100 other special illustrations. The report (four parts) you reviewed has been printed to the number of but 1,733 copies for the use of Congress, and it has cost something less than $\$ 4,000$. The other reports cost in all about $\$ 2,500$ - a total estimate of $\$ 6,500$. Since that publication, Congress has appropriated $\$ 6,000$ more for Irrigation Inquiry. How much of this has been used I do not know; some of it I am aware has been wasted and I make the remark advisedly, as much as I regret to say anything except in approval of the Department of Agriculture.

The account stands then:-

A. Ten thousand copies $(5,000$ each volume under a general provision of law) of two reports, and some other reprinting by the U. S. Geological Survey, with a number of reservoir sites reserved on the public lands, most of which have been restored under later law by the Land Office to the Public Domain; the cost of all, at least, $\$ 465,000$.

$B$. Eight reports in all by the Office of Irrigation Inquiry, Departmant of Agriculture, - three of the Engineers, three of the Geologists, and the same number of the Agent in charge (myself) - in all seven parts or volumes, containing the matter in brief, already stated, all this, too, in cost has been less than $\$ 80,000$.

The Weather Service volume (chiefly Mr. Glassford's work) is above criticism and that of the U. S. Census Office in its "Irrigation Division" work is only an adjunct to the U. S. Geological Survey, unduly fostered by the Secretary of the Interior and the Superintendent of the Census to enable Director Powell to do that which the 51st Congress by witbdrawal of a specific appropriation had forbidden him doing, viz., continue the work of irrigation survey and inquiry. The agent in charge was formerly an hydrographer in the Survey and was transferred to the Census. He has done better than it could have been anticipated he would from his first bulletins, but the work has cost far more than it is worth. That, too, from the value of the conditions and not the ability of the agent himself. Of course, it will be noticed most because it has the benefit of the expensive printing and publishing of the Census Office.

This whole irrigation inquiry has been characterized by a wasteful scramble to get in or on it. The State Department has published a volume thereon; the Treasury's Bureau of Statistics has dabbled therein in its volumes on "Internal Commerce"; the General Land Office has had its shy; the Weather Service is discussing " Earth Moisture," etc., and the Army Engineer Office got in a little one on Egypt. The Department of Agriculture only did what it was ordered and of late months not all of that. RichaRD J. HiNTON.

Washington, Dec. 26. Member Am. So. of Irrigation Engrs.

\section{Geographical Variation in Birds}

In ornithology geography is the father of trinomial nomenclature. Climate is one great factor in variation, and topography has not a little to do with making the climate; but geography is unquestionably the cause of variable climate, else would the polar regions be tropical instead of frigid. Topography is at best local.

The variations of a species of birds, which make of it several sub-species, are due to its geographical distribution. These varying individuals do not take the name of "forms," as in entomology, but are set apart as true sub species, each with a more or less well defined habitat of its own. But there is a serious difficulty in ascribing any sharp line of difference between the forms which intergrade on the outskirts of the geographical range, and a corresponding difficulty in ascribing any definite geographical limit. It is not seldom that individuals of one sub-species are found far within the range of another sub-species. 
It is a little singular that certain species do not vary, species which are not only found from ocean to ocean in North A merica. but which are nearly or quite cosmopolitan. Why this should be true of some species and not of others is still an open question. If the scorching sun of the desert regions will bleach out one species why will it not do the same for another? The plea of adaptation of coloration for protection cannot be urged $b \in$ re.

Not only are colors affected, but size as well, by geographical position. This is probably more marked north and south than east and west. And yet the variation in size alone is not sufficient for a subspecific division. It is not at all strange that those individuals of a migratory species which push farthest north should possess stronger bones and muscles, and so be larger than those which were not able to fly so far. It would seem natural that the constant recurrence of such a difference would tend, in time, to form a race peculiar enough to be recognized as a sub species. But it has not proven true thus far in the history of the world, and why should there be any change under the same conditions?

Oberlin, Ohio, Dec. 26.

LYNDS JONES,

\section{On the Use of the Compound Eyes of Insects.}

IN an interesting note on the above subject by Mr. E. T. Lewis in Science of Dec. 2, there is a reference to my note on Professor Exner's beautiful researches on the question of how the compound eyes of insects see, in my recent edition of "The Microscope and Its Revelations." Mr. Lewis says (p. 315), "but it may be as well to note that the figure on page 908 of "The Microscope and Its Revelations' appears to have been laterally inverted by the engraver," his observations enabling him to say "that in the original photograph the letter $R$ was not reversed as shown in the wood-cut, and the church faced the other way."

This is entirely fallacious; the wood-cut in the current edition of the "Revelations of the Microscope" is in every sense correct. It has been seen by Exner, and was copied from the original photograph, which now lies before me as sent me by Professor Exner himself; and a study of "Die Physiologie der Facettirten Augen von Krebsen und Insecten" will make this clear.

Lee, London, S.E., England.

W. H. Dollinger.

\section{Discovery of Mexican Feather-Work in Madrid.}

THERE are not many well-preserved specimens of native Mexicae feather-work in existence, and every addition to their number is of interest and importance. During a recent visit to the land which gave birth to the conquerors of Mexico, Mrs. Zelia Nuttall - whose researches on Mexican antiquities are well knownwas so fortunate as to discover a fine example of Mexican feathermosaic in the shape of a valuable shield, with an authentic history, preserved in the Royal Armory of Madrid. It is known as the shield of Philip the Second, for whom it was indubitably made in Spain of cane and leather in the oval shape of the Moorish adarga. It was then sent out to Mexico with four beautiful Spanish designs of historical scenes and a central derice. These were executed in Mexico entirely of feather-mosaic, which covers the whole surface of the shield and makes it one of the most surprising and superb examples of this curious lost art of miniature painting with feathers. Mrs. Nuttall has paid considerable attention to the subject of ancient Mexican feather-work, and has already accumulated novel data which promise to throw light on the methods of its manufacture. We may look for an interesting paper on this subject from her pen before long.

Soon after the shield in question was identified by ber as of Mexican workmanship - an unrecognized fact which was not recorded in the oldest Inventories - it was removed from the Royal Armory and placed on exhibition in the interesting HispanoAmerican Historical Exposition in Madrid. In the Spanish section of the same building may now be found also the elaborate tables, fourteen metres long, originally dasigned to illustrate Mrs. Nuttall's "Preliminary Note on the Ancient Calendar of the Axtecs," which formed the most original and valuable communication presented to the recent Americanist Congress at Huelva. It was then generally admitted that Mrs. Nuttall had fairly solved the great problem which has long puzzled Mexicanist students in general. Guided by a luminous passage occurring in an unpublished Hispano-Mexican MS. which she had previously discovered in a Florentine library and intends to reproduce in fac-simile, Mrs Nuttall may be said to have furnished the key to the hitherto unknown calendar system of the ancient Aztecs. It now seems to be of a very simple and harmonious character and to have been employed by them, judging from astronomical calculations, for a period of at least 4,000 y ears.

The Mexican cycle, it appears from these researches, was one of 13,515 days. It comprised 52 ritual years, less five days at the end of the cycle, each year of 260 days, or 51 lunar years of 265 days, based on nine moons in each year, or 37 solar years of 365 dass in each year. At the end of the fifty-first lunar year ten intercalated days made the lunar year equal to the solar year, in such a manner that the new cycle began in the same lunar and solar positions as the preceding cy cle of 13,515 days. Each period began with a day bearing one of four names, acatl, tecpatl, calle', or tochtle'

This is the most important discovery hitherto made known by the indefatigable Nahuatl scholar. Full details will eventually be published in one of the Peabody Museum papers of the American Museum of Archæology, on which Mrs. Zelia Nuttall, special assistant in Mexican archæology, and director of the same department in the Columbian Exhibition, has already reflected much honor. AGNES CRANE.

Brighton, England, Dec. 20, 1892.

\section{Is it Instinct or Intelligence ?}

I HAVE a nearly pure-blooded water spaniel. Though a great pet and most valuable watch-dog, in my busy life I have devoted little time to trainıng him, - rather have watched carefully the development and application of his own powers, under a uniformly kind treatment. When only five weeks old, he made his first debut into the open world, - following mother and myself to church. Crossing the street, we heard the patter of little feet, and, looking around, I saw his nose close to the ground as the little ball trulged along. I took him home and started again, only to have the performance repeated, but this time I shut him in the house. Just as church service opened, mother thought she felt something strangely warm at her feet. And lo! there was Master Carlo. He had escaped, perseveringly follow ed our track around two blocks, and discovered mother in the congregation. From that time a remarkably keen scenc has been a prominent quality. Early he manifested a love for watching and chasing chickens, - a pastime not to be neglected with the small opportunities of the city. We soon. by kindnc ss and firmness and much talking, broke him of disturbing our own chickens. We often took a little chick in our hands, and said to him "pretty chickey, Carlo's chickey!" and allowed bi " to lick it gently. Soon it was not only safe, but safer to have him in the pen with the chicks than otherwise, as then no rat or mouse dared venture there. From the tirst, 'arlo has deemed these marauders worthy of death whenever and wherever seen. and acts out his convictions. As the chickens grew, and rhanksgiving approached, their number was reduced to twelie, and these were transferred to the barn. Every nioht 'or two years Carlo made a detour of the perches, giving each fowl a $0^{\circ}$ )d lick, - they were so acquainted it did not alarm them at all, - and if one or more of the number was absent, he would itumeliately scour the premives till it was found, then gave a $p+c u$ rark indicating the discovery; nor would be ive it un till he numher was complete. Could he count? How did he wow there should be just twelve-no more, no less? Occasionally a stray fowl would come to our yard. This he tommled by keeping it constantly "on the move." not by making if a a but simply kept it walking about, persistently, unles is 1 , th the street, when be considered it game, and pursued it thor u hly. The following spring and summer, as the chicks ba ' t" lay. he took it upon himself, without any teaching to find and bring in the eggs, never sucking any, and rat no ing them if broken, it was because he laid them dow " ly upon the veranda flour. When a 